Reprod. Nutr. Dévelop., 1986, 26 (1 A), 1-11.

\title{
Milking lactating mares using oxytocin : milk volume and composition
}

\author{
M. DOREAU, Sylviane BOULOT, W. MARTIN-ROSSET $\left({ }^{*}\right)$, H. DUBROEUCQ $\left({ }^{*}\right)$ \\ Station des Productions bovines et chevalines, \\ Laboratoire de la Lactation, \\ (*) Unité Elevage et Alimentation du Cheval, \\ I.N.R.A., Theix, 63122 Ceyrat, France.
}

Summary. Ten lactating mares were milked using oxytocin 5 times during the first two months of lactation. The two sides of the udder were milked alternatively and $60-\mathrm{ml}$ fractions (from each side) were sampled for the analysis of fat, protein and lactose :

- the total amount of milk depended on the time elapsed since the milk was last drawn from the udder by sucking. When that time was 90 min (at 2 months of lactation), a mean amount of $1200 \mathrm{ml}$ was reached; the maximal value was $2185 \mathrm{ml}$;

- the amount of milk collected before oxytocin injection was on the average $40 \%$ of the total but varied between 2 and $79 \%$; there was no individual effect ;

- the accuracy of milking as a method of estimating mare's milk was low when the deuterium oxide dilution technique was used as a reference ;

- the fat content of the milk increased during milking with a specific effect of oxytocin injection (fig. 3). Variations in protein and lactose were not significant.

\section{Introduction.}

Measurements of milk production and composition can be used to gain knowledge of the nutritional requirements of mares and the growth of their nursing foals. Oxytocin injection promotes udder emptying by stimulating milk ejection.

The estimation of milk production by milking with oxytocin injection has been extensively studied in cows and ewes (Ricordeau and Denamur, 1962 ; Doney et al., 1979 ; Le Du et al., 1979 ; Oftedal, 1984). The quantity sucked by offspring is generally overestimated, especially during early lactation, since it includes residual milk. Because the composition of milk (especially fat) varies during udder emptying of ewes and cows, it is necessary to carry out analysis after complete milking (Gilmore and Gaunt, 1963 ; Labussière, 1969).

The effect of oxytocin on milk release in lactating mares is not known. However, mares milked without oxytocin deliver less than $500 \mathrm{ml}$ at each milking (Bilek et al., 1955 ; Ullrey et al., 1966 ; Johnston et al., 1970), whereas those milked with oxytocin give a mean $1000 \mathrm{ml}$ (Oftedal et al., 1983) and a maximum of $2000 \mathrm{ml}$ (Neuhaus, 1961). The above authors did not determine daily milk production. Ashcraft and Tyznik (1976) made an estimate on one side by milking 
without oxytocin while the foal sucked the other. This milk yield, lower than all other estimates in the literature, was probably underestimated.

Mare's milk fat increases during milking (Prowosnik, 1931 ; Dittrich, 1938 ; Dyusembin, 1972a ; Cherepanova and Belokobylenko, 1974) but since there is a lack of details in these data, we undertook a more complete study.

After standardizing a milking technique using oxytocin, milk quantities and fat, protein and lactose concentrations were measured on each side of the udder, before and after oxytocin injection and at five stages of lactation. This estimate of milk yield was compared to an accurate one, using deuterium oxide dilution in the foal body, as proposed in mares in a previous paper (Doreau and Dussap, 1980).

\section{Material and methods.}

Experimental design. - Ten mares of two French heavy breeds (Bretonne and Comtoise) were maintained each in a box with their foal during the first 8 weeks of lactation. The mares were 5 to 15 years old, multiparous and weighed about $800 \mathrm{~kg}$ after foaling. In normal management conditions, the foals suck freely. They may eat hay but intake is known to be low up to 2 months (Martin-Rosset, Doreau and Cloix, 1978). The foals in our experiment were not allowed to drink water while milk production was measured by deuterium oxide labelling. So water intake was obtained almost exclusively from the milk.

The mothers were fed hay-concentrate diets ad libitum at a $50: 50$ (5 mares) or 95 : 5 (5 mares) ratio. Hay was a second cut of tall fescue ; a soybean meal concentrate (diet $95: 5$ ) or a cereal and soybean meal (diet : $50: 50$ ) was given so that the nitrogen requirements were met. The mares were milked on days 2, 8, 15, 29 and 57 after foaling. Milk yield measurements using the deuterium oxide dilution technique were centered around days 6, 27 and 55 .

Nutritional data concerning the effect of diet on milk yield and composition and the relationship to foal growth will be published elsewhere (Doreau et al., 1986 and unpublished).

Milking procedure. - The mares were hand-milked at about $3 \mathrm{p} . \mathrm{m}$. when the sucking frequency of the foals was close to the mean daily frequency (Schoen, Banks and Curtis, 1976). This single milking was taken as representing the mean quantity of milk consumed by the foal in one suckling. The time between the last sucking and milking was equal to the mean time between two sucklings, estimated from behavioural data on mares of the same breeds (Martin-Rosset, Doreau and Cloix, 1978) : 30, 40, 50, 60 and 90 min for days 2, 8, 15, 29 and 57 after foaling. The mares were always milked by the same milker. The following sequence was used:

- a muzzle was put on the foal for longer than the mean interval between two sucklings ;

- the muzzle was removed and the foal allowed to suck. The hungry foal emptied the udder almost completely ;

- the muzzle was put back on the foal during the mean interval between two sucklings ; 
- the mare was milked without any special udder preparation. When milk ejection stopped, $40 \mathrm{IU}$ of oxytocin were injected intravenously and the mare was milked. The foal was left in the box with its mother to minimize the mare's stress. The whole procedure lasted between 5 and $12 \mathrm{~min}$;

- the muzzle was removed, and since the efforts of the foal to suck were unsuccessful, the udder was assumed to be well emptied.

Milk sampling. - At each milking, the milk, totally collected in 60-ml fractions in flasks, was taken alternatively from the right or left side before and after oxytocin injection. The first fraction milked and the first one collected after injection were taken from the right side. When one side was emptied, the other was milked until empty. This sampling procedure allowed us to calculate the quantity of milk obtained from each side before and after oxytocin injection. The corresponding fat, protein and lactose concentrations were also measured.

Daily milk yield was estimated by the formula $Y=M \times \frac{24}{1}$, where $M$ was the quantity of milk collected by milking and I the interval between the last suckling and milking (in hours).

All $60-\mathrm{ml}$ fractions of milk were analysed using the Gerber volumetric method for fat content and infra-red spectrophotometry for lactose and protein contents. This method, calibrated with cow's milk, led to a slight overestimation of the protein content, but the relative variations during milking were probably independent of the method (Doreau et al., 1985).

Estimation of milk yield by the deuterium oxide dilution technique. - This method has been described by Doreau and Dussap (1980). In this trial, deuterium oxide was injected intravenously $(0.6 \mathrm{~g} / \mathrm{kg}$ live weight) at $9 \mathrm{a} . \mathrm{m}$. Blood samples were taken at 3 p.m. four times during 5 days after injection. The hypothesis for calculating milk dry matter content and the production of metabolic water, as estimated in the previous paper, was maintained. No correction was made for hay intake ; a maximal intake of $1 \mathrm{~kg}$ of hay at 2 months leads to a calculated water intake (including metabolic water) of only $0.3 \mathrm{~kg}$.

\section{Results and discussion.}

Amount of milk collected (table 1). - Total amounts varied significantly with physiological stage and diet. The effect of the first was chiefly the consequence of the increasing intervals between the last suckling and milking 130 to $90 \mathrm{~min}$ according to the stage). The amounts per unit of time were less variable. They decreased slightly, but not significantly ; standard deviations were high during the colostral stage and week 1 . This seemed to show a maximal rate of secretion as soon as foaling occurred.

The coefficient of variation in milk quantity was high during the colostral stage : $70 \%$; it decreased to $33 \%$ at week 2 and to $18 \%$ at week 8 . The mean difference between the two diets, not detailed in this paper, was $273 \mathrm{ml}$. The 


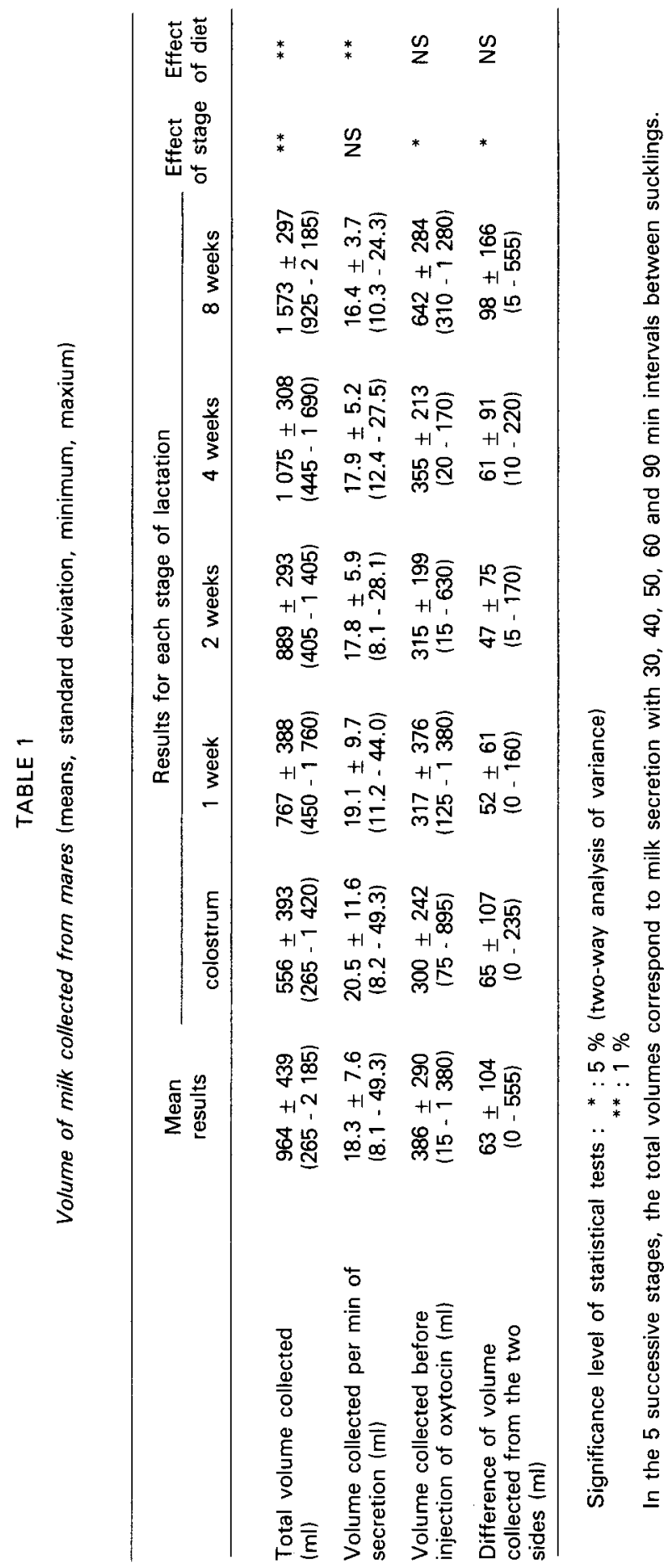


analysis of variance did not show any significant individual effect. Some mares gave very different amounts of milk from one week to another and sometimes more during the colostral stage than in week 4 of lactation.

The maximal amount of milk collected was $2185 \mathrm{ml}$ for a 90 -min interval between the last suckling and milking. This value was close to the maximal values obtained by Neuhaus (1961) and to data from the Soviet Union, with dairy mares weighing about $500 \mathrm{~kg}$ (see review of Doreau and Boulot, 1986). Only a few authors obtained greater amounts. However, Fedotov (1965) and Fedotov and Duisembaev (1974) respectively obtained 2600 and $2700 \mathrm{ml}$ of milk with one milking. The results are not easy to compare because in the literature the duration of secretion between the last emptying of the udder and milking is not indicated. Moreover, in our trial, maximal udder capacity may not have been reached with a 90-min secretion.

The amount of milk collected before oxytocin injection (fig. 1) depended on the physiological stage but not on the diet; on the average, it was $40 \%$ of the total amount. This ratio varied between 2 and $79 \%$ but no effect of physiological stage, diet or animal was found. One mare spontaneously (i.e. before injection) gave $220 \mathrm{ml}$ of milk in the colostral stage and $10 \mathrm{ml}$ in week 4 of lactation. The lack of individual effect is surprising; other workers indicate great individual variations in milk retention (Cherepanova and Belokobylenko, 1974). Moreover, we did not find any relationship between the apparent calm or stress of the mare and the amount of milk collected without oxytocin injection. Perhaps the muzzled foal caused a release of oxytocin during an attempt to suck, inhibiting further release during milking.

The volume collected after injection $\left(V_{2}\right)$ was poorly related with the volume collected before injection $\left(V_{1}\right): V_{2}=0.32 V_{1}+453(r=0.40, n=50$,

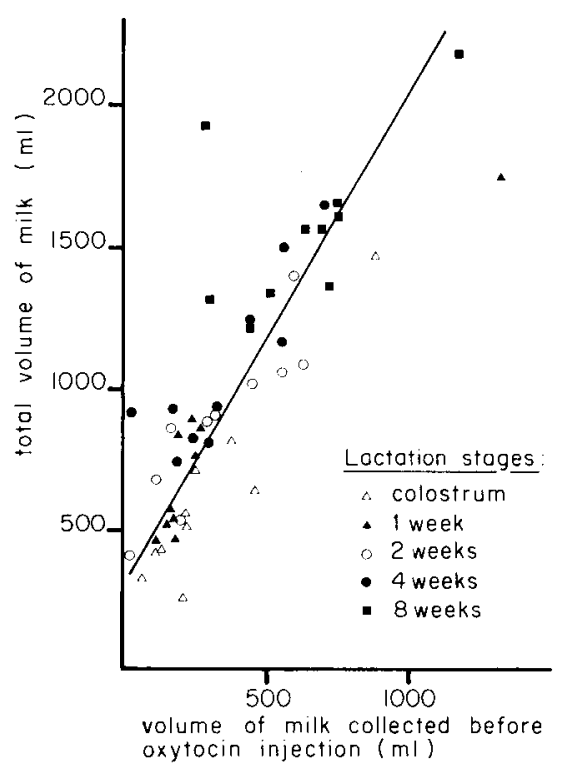

FIG. 1. - Relation between total volume of milk and volume collected before injection of oxytocin. 
$P<0.01, V_{1}$ and $V_{2}$ in $\left.\mathrm{ml}\right)$. However, the total volume $\left(V_{T}\right)$ could be roughly predicted with $V_{1}$ (fig. 1) : $V_{T}=1.72 V_{1}+295\left(r=0.87, n=50, P<0.01, V_{1}\right.$ and $V_{T}$ in $\mathrm{ml}$ ).

In 2 milkings out of 50, oxytocin was injected a second time because only 15 and $20 \mathrm{ml}$ of milk were collected before the first injection. The amount collected after the second injection was $8 \%$ of the total. The dose of oxytocin per $\mathrm{kg}$ of live weight was slightly higher than in the trials of Neuhaus (1961) or Oftedal et al. (1983). When related to blood volume, it probably led to maximal plasma concentrations measured during suckling (Sharma, 1974) or during dairy mare milking (Kuanyshbekova, 1975). However, the dose we used was very high in comparison with those generally injected in cows. The very small volume sometimes collected without injection could indicate that the cistern of the udder had a very limited capacity or was not full when the ducts were. Tumanova (1966) indicates a cistern volume of 200 to $300 \mathrm{ml}$. Masloboev (1961) has estimated it as $10 \%$ of total udder capacity, and Cherepanova and Belokobylenko (1974) as between 40 and $100 \%$; however, anatomical observations (Barone and Monnet, 1955) show the total capacity of udder cisterns to be about $60 \mathrm{ml}$ in dry mares.

The increase in the amount of milk given spontaneously by mares between the colostral stage and week 8 of lactation was perhaps due to familiarization with milking. More probably, it was caused by an increase in the volume of milk in the udder ; intramammary pressure can stimulate the myoepithelial cells, as in other species (Denuccio and Grosvenor, 1971).

The right side of the udder gave a mean of $12 \%$, or $63 \mathrm{ml}$ more milk than the left side. For $18 \%$ of the milkings, however, the left produced more milk than the right. The difference between the two sides varied within the extreme values of 0 and $555 \mathrm{ml}$ (table 1). It depended neither on physiological stage nor on diet. Two mares gave rise to the difference, which was small in the other 8 animals. The difference between the two sides was not significant for the milk collected before oxytocin injection (mean of $17 \mathrm{ml}$ ) but was significant for the milk collected after injection. Neuhaus (1961) has shown that the first side milked produces $35 \%$ more milk than the other. The milking procedure in this trial could partially explain the difference observed. However, the quarters may not be physiologically symmetrical.

Comparison of the two methods for estimating milk production. - The relationship between the individual values obtained by milking or $\mathrm{D}_{2} \mathrm{O}$ dilution at the same stage of lactation was not significant $(r=0.17)$. Moreover, one of the data obtained by milking was aberrant $(63.4 \mathrm{~kg})$. We considered the $\mathrm{D}_{2} \mathrm{O}$ dilution technique to be the reference : it had been verified by Dove and Freer (1979) and Doreau and Dussap (1980) in lambs fed milk from a bottle. In this trial, the correlation coefficients between $\mathrm{D}_{2} \mathrm{O}$ concentration and time were between 0.990 and 0.999 . The main purpose of milking was to determine variations in milk composition. The natural conditions of nursing seemed to be optimized when the secretion time before milking came after the udder had been emptied as much as possible by suckling. When the estimation of the rate of milk secretion is the most important measurement, the best method is milking after a given secretion time, 
once the udder has been emptied by oxytocin injection. So, the method used here might slightly overestimate the milk secretion rate. However, the amount of residual milk is unknown.

Up to week 4 of lactation, the estimation of milk production was higher by milking than by $\mathrm{D}_{2} \mathrm{O}$ dilution, but at 4 and 8 weeks of lactation, the two means were similar (fig. 2). However, the relationships between the two methods were different when the mares were classed according to mean milk production : for the 5 lowest producers, the two methods gave similar results between weeks 1 and 8 ; for the 5 highest producers, production was overestimated by milking before 2 weeks and underestimated after 4 weeks. These results must be interpreted with caution owing to wide individual variation. Nevertheless, during the first week of lactation, the difference between the two methods might be explained by the fact that the foal's appetite was not enough to drive it to empty the udder : this is also true in sheep (Ricordeau and Denamur, 1962) and cattle (Le Neindre et al., 1976). At weeks 4 and 8 , underestimation by milking might be due to the frequency of foal sucking which could be higher than expected in the high producers. According to Masloboev (1961), daily milk production drops when the interval between milking increases from $45 \mathrm{~min}$ to $2 \mathrm{~h}$. However, sucking frequency has never been related to milk intake.

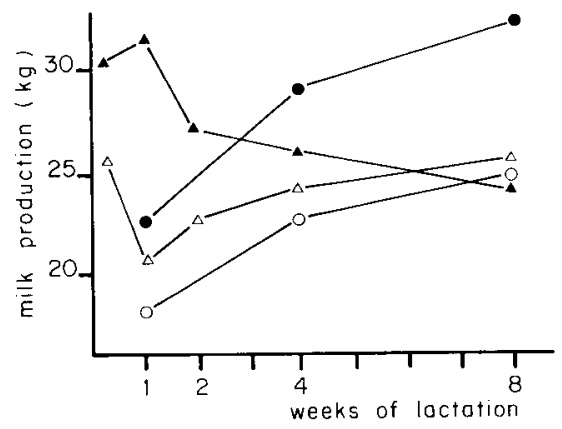

FIG. 2. - Comparison of two methods to estimate mare's milk production : effect of lactation stage and level of milk production. $-\mathrm{D}_{2} \mathrm{O}$ dilution in foal body, high producers ; $\boldsymbol{\Delta}$ : milking mare, high producers: $0: \mathrm{D}_{2} \mathrm{O}$ dilution in foal body, low producers ; $\triangle$ : milking mare, low producers.

Therefore, the estimation of mare's milk production by milking was not reliable in our experimental conditions. One milking was probably not enough to obtain a good estimate. Several successive milkings might have a galactopoietic effect (Dyusembin, 1972a). Moreover, our knowledge of the lactation physiology and behaviour of the mare is, at present, too limited to replicate nursing by milking.

Milk composition. - The milkings included 4 samples of about $120 \mathrm{ml}$ of milk from both sides of the udder $(60 \mathrm{ml}$ from each side) : (1) : first fraction milked; (2) : last fraction collected before oxytocin injection; (3) first fraction collected after oxytocin injection ; (4) : last fraction milked.

Milk composition during milking varied whatever the diet, mare or stage of lactation. Figure 3 shows that fat concentration rose considerably as soon as oxytocin was injected. The protein and lactose concentrations fell only between 


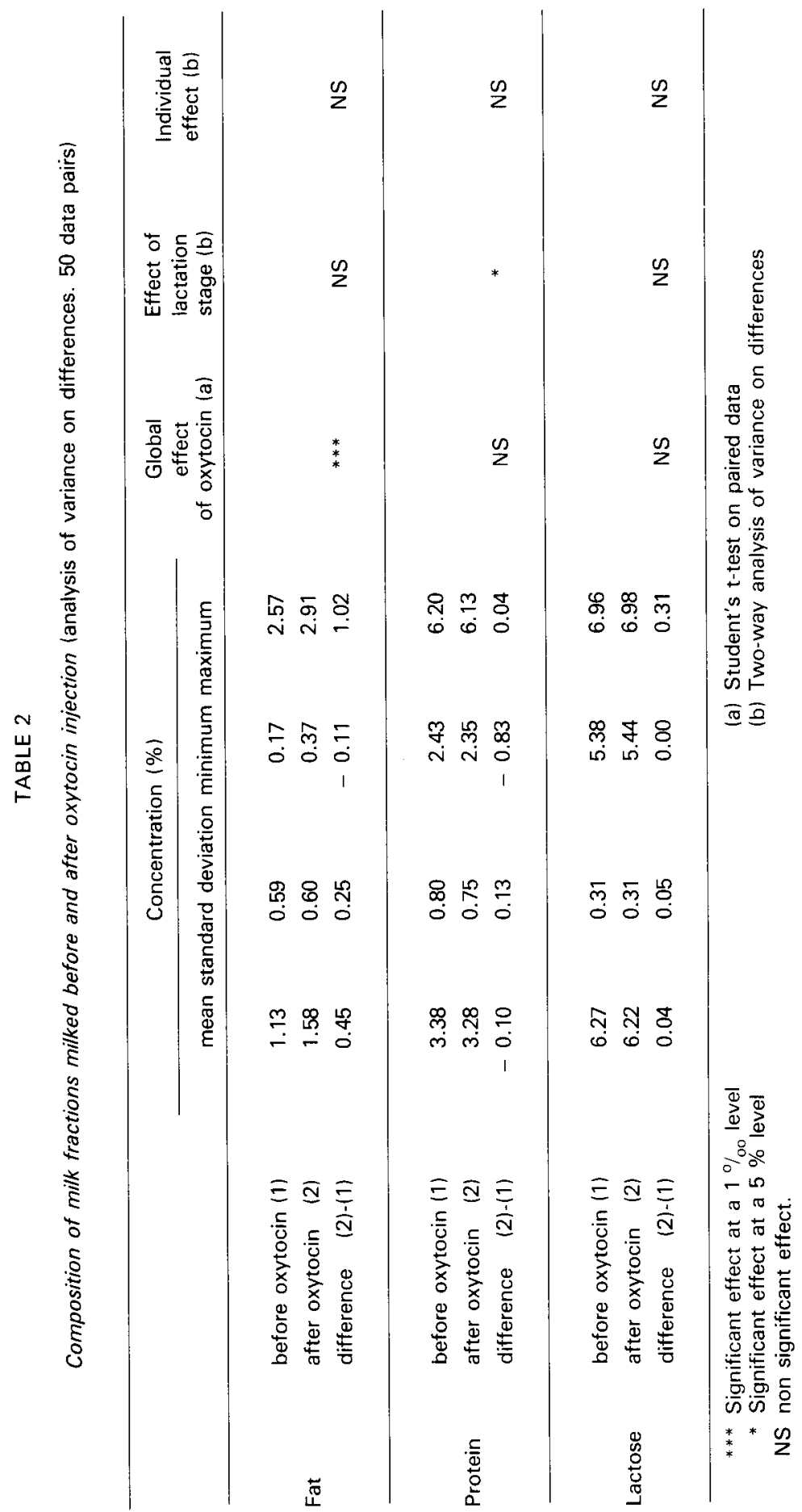


fractions 3 and 4 . The increase in milk fat content during milking was verified in the mares; there were fewer variations between milking onset and end than previously reported (Cherepanova and Belokobylenko, 1974). This can be explained by a difference in udder emptying. There was no large increase between the last fraction and the preceding one. Fat content at the onset of milking was variable, sometimes being less than $1 \%$. This might explain why Neuhaus (1959) reported some zero milk fat content.
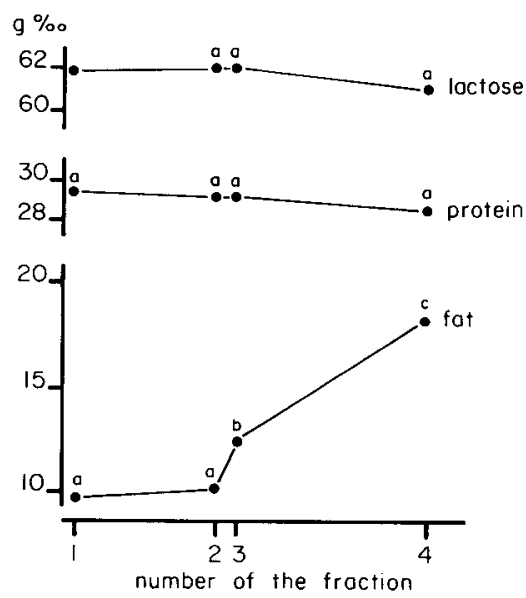

FIG. 3. - Variations in fat, protein and lactose concentrations during milking. Fractions 1 to 4 $(60 \mathrm{ml}$ milk from each quarter) are defined in text. Means with different superscripts differ $(\mathrm{P}<0.05)$.

The slight decrease in protein and lactose contents at the end of milking, already observed in other species (see review of Labussière, 1985), can be partially $(0.2 \%)$ explained by a passive variation caused by the increase in fat content.

As a result of these variations, it is necessary to milk mares after oxytocin injection in order to collect a representative sample for milk composition analysis. Table 2 shows a significant difference in fat content between samples collected before and after oxytocin injection, whatever the physiological stage. These differences vary greatly with the mare. The errors committed in milking without oxytocin were always less than 0.4 and $0.9 \%$ for the lactose and protein contents, respectively. The error in fat content could reach $5 \%$ but was less than $2 \%$ in half of the milkings.

There is no significant difference in composition between the two sides when all the samples are considered. During the colostral phase, however, the left side, which gave less milk, had a $2 \%$ higher fat content than the right side. In the two mares which had a very different milk volume in the two sides, the left side had a higher fat content. 
Résumé. Traite des juments allaitantes à l'aide d'ocytocine : volume et composition du lait recueilli.

Dix juments allaitantes ont été traites à l'aide d'ocytocine à 5 reprises durant les deux premiers mois de lactation. Les deux quartiers étaient traits alternativement par fractions de $60 \mathrm{ml}$ recueillies pour analyse des matières grasses, protéines et lactose :

- la quantité de lait recueillie a varié avec la durée de sécrétion de la mamelle depuis la tétée précédente. Quand cette durée était de 90 min (à 2 mois de lactation) elle a atteint en moyenne $1200 \mathrm{ml}$; la valeur maximale a été de $2185 \mathrm{ml}$;

- la quantité de lait collectée avant l'injection d'ocytocine a été en moyenne de $40 \%$ de la quantité totale, mais a varié entre les valeurs extrêmes de 2 et $79 \%$; il n'y a pas eu d'effet animal sur cette proportion ;

- I'utilisation de la traite pour estimer la production laitière des juments semble peu fiable, lorsqu'elle est comparée à la méthode de diffusion de l'eau lourde dans l'organisme du poulain, considérée comme référence ;

- la teneur en matières grasses du lait s'est accrue au cours de la traite, avec un effet spécifique de l'injection d'ocytocine (fig. 3). Les variations des teneurs en protéines et en lactose $n$ 'ont pas été significatives.

\section{References}

ASHCRAFT A., TYZNIK W. J., 1976. Effect of diet on volume and composition in mare's milk. J. anim. Sci., 43, 248 (Abstr.).

BARONE R., MONNET C., 1955. Les mamelles des équidés domestiques. Bull. Soc. Sci. vét. Lyon, 57, 73-92.

BILEK J., DUSEK J., LECHNER F., 1955. New knowledge of the methods of milking mares and of effects on the secretion of mare's milk (in Czech). Sborn. cs/. Akad. zemed. Ved., 28, 859886.

CHEREPANOVA V. P., BELOKOBYLENKO V. T., 1974. Milk ejection characteristics in machine milking of mares. Proc. $3^{\text {rd }}$ All. Union Symp. Physiol. Principles of machine milking, 116-117. Dairy Sci. Abstr., 37, 7104.

DENUCCIO D. J., GROSVENOR C. E., 1971. Effects of volume and distribution of milk on the oxytocin-induced contraction of the lactating rat mammary gland in vivo. J. Endocrinol., 51, 437-446.

DITTRICH H., 1938. Untersuchungen uber die Zusammensetzung von Pferdemilch. Milchwirtschaftl. Forschg., 19, 406-412.

DONEY J. M., PEART J. N., SMITH W. F., LOUDA F., 1979. A consideration of techniques for estimating milk yield by suckled sheep and a comparison of estimates obtained by two methods in relation to the effect of breed, level of production and stage of lactation. J. agric. Sci. Camb., 92, 123-132.

DOREAU M., BOULOT S., 1986. Production et composition du lait de jument : revue bibliographique (in progress).

DOREAU M., BOULOT S., JEUNET R., TRIN J. M., 1985. Comparaison de différentes méthodes de dosage de la matière grasse et de la matière azotée du lait de jument. Le Lait, 65, 145-157.

DOREAU M., BOULOT S., MARTIN-ROSSET W., ROBELIN J., 1986. Relationship between nutrient intake, growth and body composition of the nursing foal. Reprod. Nutr. Dévelop., 26 (2 B) (in press).

DOREAU M., DUSSAP G., 1980. Estimation de la production laitière de la jument allaitante par marquage de l'eau corporelle du poulain. Reprod. Nutr. Déve/op., 20, 1883-1892.

DOVE M., FREER M., 1979. The accuracy of tritiated water turnover rate as an estimate of milk intake in lambs. Austr. J. agric. Res., 30, 725-739.

DYUSEMBIN K. H., 1972a. Uneven distribution of major milk components in consecutive portions of a milking in farm animals (in Russian). Trudy Inst. Fiziol. Alma-Ata, 17, 42-45.

DYUSEMBIN K. H., 1972b. The role of oxytocin in regulating lactation in mares (in Russian). Trudy Inst. Fiziol. Alma-Ata, 17, 37-41. 
FEDOTOV P. A., 1965. Milk yield of Kazakh mares and crosses with Russian Trotter and Kustanaï horses kept in herds (in Russian). Vest. sel'-khoz. Nauki, Alma-Ata, 8, 47-54.

FEDOTOV P. A., DUISEMBAEV K., 1974. Morphological characteristics of mare's udders. Genet. selekt, rast. zhiv. Kazakh, 265-266.

GILMORE H. C., GAUNT S. N., 1963. Variation in per cent of protein, milk fat and solids not fat between milking and during milk process. J. Dairy Sci., 46, 680-685.

JOHNSTON R. H., KAMSTRA L. D., KOHLER P. H., 1970. Mare's milk composition as related to foal heat scours. J. anim. Sci., 31, 549-553.

KUANYSHBEKOVA G. A. 1975. Oxytocin activity of blood in lactating mares (in Russian). Trudy Inst. Fiziol. Alma-Ata Kazakhs SSR, 21, 128-131.

LABUSSIĖRE J., 1969. Importance, composition et signification des différentes fractions de lait obtenues successivement au cours de la traite mécanique des brebis. Ann. Zootech., 18, 185196.

LABUSSIĖRE J., 1985. Composition du lait et techniques de traite chez quelques espèces domes tiques. Bull. tech. C.R.V.Z. Theix, I.N.R.A., 61, 49-58.

LE DU Y. L. P., MacDONALD A. J., PEART J. N., 1979. Comparison of two techniques for estimating the milk production of suckler cows. Livest. Prod. Sci., 6, 277-281.

LE NEINDRE P., PETIT M., MULLER A., 1976. Production laitière des vaches normandes à la traite ou à l'allaitement. Ann. Zootech, 25, 533-542.

MARTIN-ROSSET W., DOREAU M., CLOIX J., 1978. Etude des activités d'un troupeau de poulinières de trait et de leurs poulains au pâturage. Ann. Zootech., 27, 33-45.

MASLOBOEV A. J., 1961. Characteristics of lactation in mares (in Russian). Trudy Vses. Inst. Konevodstva, 23, 135-150.

NEUHAUS U., 1959. Milch und Milchgewinnung von Pferdestuten. Z. Tierzucht., 73, 370-392.

NEUHAUS U., 1961. Obtaining mares, milk for the feeding of human infants. WII/th. int. Congr. anim. Prod. (Hamburg), II, 184-185.

OFTEDAL O. T., 1984. Milk composition, milk yieid and energy output at peak lactation : a comparative review. Symp. Zool. Soc. Lond., 51, 33-85.

OFTEDAL O. T., HINTZ H. F., SCHRYVER H. F., 1983. Lactation in the horse: milk composition and intake by foals. J. Nutr., 113, 2196-2206.

PROWOSNIK L., 1931. Neue Untersuchungen über die Zusammensetzung der Pferdemilch. Z. Zuchtgskde, 6, 329-338.

RICORDEAU G., DENAMUR R., 1962. Production laitière des brebis Préalpes du sud pendant les phases d'allaitement, de sevrage et de traite. Ann. Zootech., 11, 5-38.

SCHOEN A. M. S., BANKS E. M., CURTIS S. E., 1976. Behaviour of young Shetland and Welsh ponies. Biol. Behav., 1, 192-216.

SHARMA O. P., 1974. Release of oxytocin elicited by suckling stimulus in mares. J. Reprod. Fert., 37, 421-423.

TUMANOVA E. B., 1966. Certain problems of the morphological physiology of the udder of the mare (in russian). Zap. leningr. sel.'-kloz. Inst., 102, 130-134.

ULLREY D. E., STRUTHERS R. D., HENDRICKS D. G., BRENT B. E., 1966. Composition of mare's milk. J, anim. Sci., 25, 217-221. 